Instructions for authors, subscriptions and further details:

\title{
http://rimcis.hipatiapress.com
}

\section{The Role of Economic Freedom in Interpreting Corruption Perception}

Gülçin Yangın ${ }^{1}$, Serpil Kılıç Depren ${ }^{1}$

1) Yildiz Technical University

Date of publication: Online First 29 November 2021; Issue published 30 November 2021

Edition period: November 2021 - March 2022

To cite this article: Yangın, G., \& Kılıç Depren, S. (2021). The Role of Economic Freedom in Interpreting Corruption Perception. International and Multidisciplinary Journal of Social Sciences, 10(3), 40-63. doi:

10.17583/rimcis.7109

To link this article: http://doi.org/10.17583/rimcis.7109

\section{PLEASE SCROLL DOWN FOR ARTICLE}

The terms and conditions of use are related to the Open Journal System and to Creative Commons Attribution License(CC-BY). 


\section{The Role of Economic}

\section{Freedom in Interpreting} Corruption Perception

Gülçin Yangın

Yildiz Technical University
Serpil Kilıç Depren

Yildiz Technical University

\section{Abstract}

The main purpose of the study is to examine the nexus between corruption and economic freedom to determine the most influencing factors to be focused on to reduce corruption. With this aim, two different machine learning algorithms are performed to find out the single effect, two-way, and three-way interaction effects of factors affecting corruption. As a result of the analysis, tax burden, government integrity, and government spending are the main indicators to be focused on to improve corruption steadily. Besides, critical thresholds of the tax burden, government integrity, and government spending are 83.3, 50.9, and 40.6, respectively. Since there are a limited number of studies to predict corruption by machine learning algorithms in the extant literature, this research provides highly detailed information to policy-makers where they can focus on reducing corruption perception.

Keywords: economic freedom, multivariate adaptive regression splines, corruption perception 


\section{El Papel de la Libertad Económica en la}

\section{Interpretación de la}

Percepción de la Corrupción

Gülçin Yangın

Yildiz Technical University
Serpil Kilıç Depren

Yildiz Technical University

\section{Resumen}

El objetivo principal del estudio es examinar el nexo entre la corrupción y la libertad económica para determinar los factores más influyentes en los que centrarse para reducir la corrupción. Con este objetivo, se realizan dos algoritmos de aprendizaje automático diferentes para descubrir los efectos de interacción de efecto único, bidireccional y tridireccional de los factores que afectan la corrupción. Como resultado del análisis, la carga tributaria, la integridad del gobierno y el gasto público son los principales indicadores en los que se debe enfocar para mejorar la corrupción de manera constante. Además, los umbrales críticos de la carga tributaria, la integridad del gobierno y el gasto público son 83,3, 50,9 y 40,6, respectivamente. Dado que hay un número limitado de estudios para predecir la corrupción mediante algoritmos de aprendizaje automático en la literatura existente, esta investigación proporciona información muy detallada a los responsables de la formulación de políticas donde pueden centrarse en reducir la percepción de corrupción.

Palabras clave: libertad económica, splines de regresión adaptativa multivariante, percepción de corrupción 
ransparency International defines the term "corruption" as "the abuse of entrusted power for private gain" (Transparency International, 2020). Based on the definition of corruption, it can be stated that it causes weakening of trust and democracy, exacerbates inequality, poverty, and social division. These detrimental practices revealed by corruption leads to the consequences of economic, political, social, and environmental for nations. As the World Economic Forum states that the cost of corruption to the global economy is $\$ 3.6$ trillion every year, accounting for approximately $4 \%$ of the global economy (Stephen, 2018). Since corruption is a crucial indicator in terms of whether investors decide to invest in a country, governments should aim to prevent corruption as well as to measure and follow up on the corruption perception of society. With this aim, the Corruption Perception Index (CPI) has been provided by Transparency International since 1995 (Budsaratragoon, 2020).

There are several theories about corruption in the literature. Some of these theories are the principal-agent theory, the collective action theory, and the institutional theory. The principal-agent theory is defined as the mission of public officials (agents) is to protect the interest of the principal, but the interests of agents and principals can be differentiated (Groenendijk, 1997). Also, the rule of pay-off between the agent and principal is needed to be described while there is an information bias to the agent's advantage in this theory. Thus, this theory defines corruption as an agent problem that principal cannot play an effective monitoring role as a result of lack of information (Andvig \& Fjeldstad, 2001). The term systematic corruption is explained as a collective problem, which is highly related to the rationalization of people's own behavior taking into consideration the perception of what others do in the same situation (Persson, Rothstein \& Teorell, 2013). This theory assumes people believe that being the only one who is the honest person in a corrupted system is not make sense once corruption is a social norm in society (Marquette \& Peiffer, 2015). Last but not least, the institutional theory explains that corruption is affected by many different factors such as character, design, transparency, and freedom of economic and political systems and its institutions. Also, 
the theory is assumed that the nexus between these factors is extremely complex (Debski et al., 2018; Stensöta, Wängnerud \& Svensson, 2015).

There are some cross-national indices, developed by independent organizations that countries follow on different topics such as the Economic Freedom of the World (EFW) Index. The EFW index captures a wide variety of institutional determinants related to the rule of law, government size, regulatory efficiency, and open market conditions to measure the consistency of the institutions and policies of various countries (Gwartney et al., 2019; Vendrell-Herrero et al., 2020). Within the cross-country researches, it is revealed that economic freedom is one of the significant determinants of corruption, and the higher economic freedom the lower corruption (Chowdhury, 2004; Goel \& Nelson, 2007; Saha et al., 2009; de Jong \& Bogmans, 2011).

Determination of the nexus between dimensions of EFW and CPI becomes an inestimable subject of study to understand the root cause of corruption. The present study explores the relationship between the sub-components of economic freedom and corruption perception employing two different machine learning approaches. To the best of our knowledge, this study contributes to the literature on defining the potential determinants of corruption, measure the relative importance of determinants of corruption, and determine the critical thresholds of determinants to keep the corruption perception at a low level.

The remainder of this paper is organized as follows. The literature review is given in Section 2. Research focus, data, and methodology with details are provided in Section 3 and 4, respectively. Section 5 summarizes the results including the prediction accuracy and variable importance of all machine learning algorithms, followed in Section 6 by Discussion. Conclusion remarks are given in Section 7.

\section{Literature Review}

During the last decade, the interest in examining the relationship between corruption perception and some other determinants that has an impact on economic growth such as economic freedom, foreign direct investment, social progress index, and doing business opportunity increases. In the literature, many researchers are studied on making a 
connection between corruption perception and other factors thought to have an impact on corruption (Carden \& Verdon, 2010; Huang, 2016; Qaiser, Nadeem, Siddiqi \& Siddiqui, 2017; Christos et al., 2018; Fazira \& Cahyadin, 2018).

The potential reasons for corruption perception have been attempted to address by using different techniques in the literature review. Billger and Goel (2009) analyze the factors of corruption using a dataset that cross-sectional observations on 99 countries from 2001 to 2003. According to this research, it is detected that there is no statistically significant relationship between corruption and economic freedom, but greater democracy appears to reduce corruption (Billger \& Goel, 2009). On contrary to the results of the study of Billger and Goel (2009), Pieroni and d'Agostino (2013) work on determining the relationship between corruption and the effects of economic freedom by using a firm-based dataset obtained from a cross-country research questionnaire (Pieroni \& d'Agostino, 2013). The consequences of the research that the extent of the macro-effects of the microeconomic freedom for corruption, determined by the degree of economic development of a country, can cause more corruption because of government regularization policies (Pieroni \& d'Agostino, 2013). Similar to Pieroni and d'Agostino's study (2013), Konu and Ata point out that the cross-sectional analysis method in 28 European Union countries and Turkey for the impact of corruption on economic freedom employed by using the 2014 dataset. Depending on the outcome of the study, it is obtained that economic freedoms have a statistically substantial and positive impact on the CPI (Konu \& Ata, 2016). In the study of Lima and Delen (2020), it is focused on developing a prediction model for the correct classification of the CPI utilizing machine learning algorithms. As a result of the study, $73.8 \%, 85.8 \%$, and $76.2 \%$ of results are obtained by using Artificial Neural Networks, Random Forest, and Support Vector Machines algorithms, respectively (Lima \& Delen, 2020). Thus, it is shown that CPI can be modeled by using independent factors.

The purpose of Keyifli's research (2019) is to examine whether countries have a link between corruption and the e-Government Development Index. This study is conducted with 186 developed and 
developing countries with 2018 data by doing a cross-sectional analysis method. According to the analytical results are obtained from the study, it is found a statistically significant and positive impact between the implementation of e-government and corruption (Keyifli, 2019). Cuadrado-Ballesteros and Pena-Miguel (2020) deal with a perceived corruption in 22 European countries which a panel dataset with 264 observations in terms of privatization reforms by considering the role of governance quality between the years of 2002-2013. As far as empirical findings argue that corruption decreases when the quality of governance increases following privatization reforms. Furthermore; accountability, government impacts, regulating structure, the rule of law factors are crucial to hinder corruption after privatization (Cuadrado-Ballesteros \& Pena-Miguel, 2020).

Regarding the anti-corruption activities are analyzed, the instances of experience by using a knowledge system in the Republic of Tatarstan, Yamal-Nenets Autonomous region, Volgograd, and Tula zone of the Russian Federation are investigated. This study is emphasized tactics and methodology of set against corruption within the executive agencies of Russian Federation territorial entities and is proposed to compose a unique information and analysis system (Astafurova et al., 2020).

\section{Research Problem and Focus}

Regardless of the theory underlying it, corruption is the vital problem that needed to be solved, as it directly or indirectly affects all financial and social indicators of a country, once it is solved, countries can increase their level of welfare as well. Thus, the determination of the nexus between CPI and other relevant factors examined in the literature and proposing the potential action plans for policy-makers has become more important than ever in the last decades. Although measuring the bi-directional relationship between CPI and EFW has been studied in the literature, the impact of dimensions of EFW on CPI has not been examined in the extant literature. Thus, the impacts of EFW dimensions on CPI are examined in this study, which is the gap in the literature. With this way, it is aimed to answer the following questions: 
1. Which dimensions of EFW are influencing CPI significantly?

2. What is the importance level of factors affecting CPI?

3. Which precautions should be taken to improve the CPI of a country?

\section{Research Methodology}

Our dataset is integrated and processed to build the structure of the proposed methodology which is used the R Studio program.

\section{Dataset and Data Preprocessing}

Datasets of the Economic Freedom and the CPI are obtained from two different data sources which are the Heritage Foundation and the CPI, respectively. The dataset consists of 162 countries, and 486 observations in the years between 2017 and 2019.

EFW has 12 dimensions: Property Rights, Judicial Effectiveness, Government Integrity, Tax Burden, Government Spending, Fiscal Health, Business Freedom, Labor Freedom, Monetary Freedom, Trade Freedom, Investment Freedom, and Financial Freedom. The CPI uses a scale from 0 to 100 . The low index value of a country means that the corruption level is high.

The six-step analysis process is used in this study. The steps of the process are given in Figure 1.

In the first two steps of the process, datasets of dimensions of the economic freedom and corruption perception index of countries between 2017 and 2019 are collected, and then they are combined into one aggregated dataset. The descriptive statistics are given in the third step. In the fourth step, the aggregated dataset is split into two, which are the training dataset and the test dataset, under the machine learning analysis procedure. Step 5 is the model construction step in which MARS and SVM algorithms with a cross-validation approach are performed. In the last step, the model is evaluated and interpreted. 
International and Multidisciplinary Journal of Social Sciences, 10(3) 47

Table 1.

Description and sources of variables

\begin{tabular}{|c|c|c|}
\hline Code & Variable & Definition \\
\hline $\mathrm{CPI}^{\mathrm{a}}$ & $\begin{array}{l}\text { Corruption } \\
\text { Perception } \\
\text { Index }\end{array}$ & $\begin{array}{l}\text { Perception level of public sector corruption, according to experts } \\
\text { and business people }\end{array}$ \\
\hline $\mathrm{PR}^{\mathrm{b}}$ & Property Rights & $\begin{array}{l}\text { Covers the physical property rights, intellectual property rights, } \\
\text { strength of investor protection, risk of expropriation, and quality } \\
\text { of land administration }\end{array}$ \\
\hline $\mathrm{GI}^{\mathrm{b}}$ & $\begin{array}{l}\text { Government } \\
\text { Integrity }\end{array}$ & Represents the level of public trust and economic vitality \\
\hline $\mathrm{JE}^{\mathrm{b}}$ & $\begin{array}{l}\text { Judicial } \\
\text { Effectiveness }\end{array}$ & $\begin{array}{l}\text { Covers judicial independence, quality of the judicial process, and } \\
\text { favoritism in obtaining judicial decisions }\end{array}$ \\
\hline $\mathrm{TB}^{\mathrm{b}}$ & Tax Burden & $\begin{array}{l}\text { Consists of the top marginal tax rate on individual (and also } \\
\text { corporate) income and the total tax burden as a percentage of } \\
\text { GDP }\end{array}$ \\
\hline $\mathrm{GS}^{\mathrm{b}}$ & $\begin{array}{l}\text { Government } \\
\text { Spending }\end{array}$ & Represents any expenditures made by the government \\
\hline $\mathrm{FH}^{\mathrm{b}}$ & Fiscal Health & $\begin{array}{l}\text { Composed of average deficits as a percentage of GDP and debt as } \\
\text { a percentage of GDP }\end{array}$ \\
\hline $\mathrm{BF}^{\mathrm{b}}$ & $\begin{array}{l}\text { Business } \\
\text { Freedom }\end{array}$ & $\begin{array}{l}\text { Consists of the operational process of starting, obtaining, closing, } \\
\text { or getting electricity for business }\end{array}$ \\
\hline $\mathrm{LF}^{\mathrm{b}}$ & Labor Freedom & $\begin{array}{l}\text { Represents the employment opportunities in the market, } \\
\text { composed of regulations about minimum wages, laws in } \\
\text { preventing layoffs, severance pay conditions, and regulations } \\
\text { about hiring and working hours }\end{array}$ \\
\hline $\mathrm{MF}^{\mathrm{b}}$ & $\begin{array}{l}\text { Monetary } \\
\text { Freedom }\end{array}$ & $\begin{array}{l}\text { Covers the inflation rate and qualitative evaluation of price } \\
\text { manipulation done by the government via direct control or } \\
\text { subsidies }\end{array}$ \\
\hline $\mathrm{TF}^{\mathrm{b}}$ & Trade Freedom & $\begin{array}{l}\text { Represents tariff rate and qualitative judgment about non-tariff } \\
\text { barriers }\end{array}$ \\
\hline $\mathrm{IF}^{\mathrm{b}}$ & $\begin{array}{l}\text { Investment } \\
\text { Freedom }\end{array}$ & $\begin{array}{l}\text { Covers restriction such as payment and transfers on the flow of } \\
\text { investment about both internally and externally }\end{array}$ \\
\hline $\mathrm{FF}^{\mathrm{b}}$ & $\begin{array}{l}\text { Financial } \\
\text { Freedom }\end{array}$ & Reflects the banking efficiency \\
\hline
\end{tabular}

${ }^{\text {a https://www.transparency.org/ }}$

${ }^{\mathrm{b}}$ https://www.heritage.org/ 
48 Yangin \& Klliç Depren - The Role of Economic Freedom

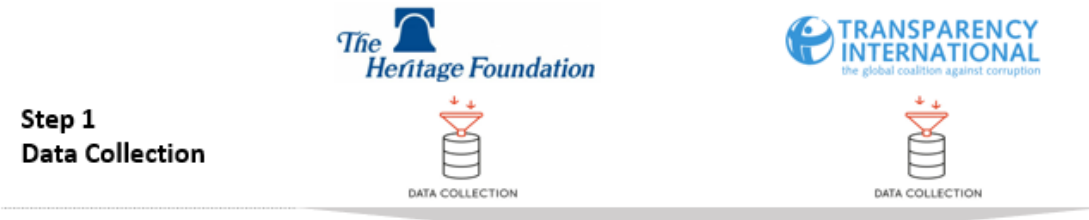

Step 2

Data Aggregation

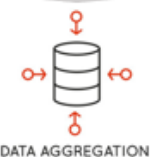

Descriptive

Step 3

Basic Statistics

Statistics

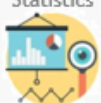

Step 4

Data Splitting

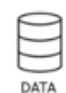

Train Dataset

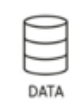

Test Dataset

\section{Step 5 \\ Model Evaluation}
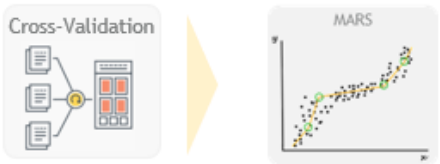

Support Vector

Machines

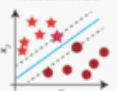

\section{Step 6}

Evaluating Results

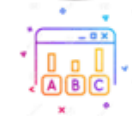

Evaluation of the Model

Figure 1. Steps of Analysis Process 
International and Multidisciplinary Journal of Social Sciences, 10(3) 49

\section{Model Building}

Multivariate Adaptive Regression Splines (MARS) is first introduced by Friedman that is a multivariate nonparametric classification and regression technique that used high-dimensional data conveniently. MARS is used for binary and continuous dependent variables to accurate predictive models. This technique gives some advantages like being flexible, innovative, handling missing values, hampering overfitting, and quickly identifying optimal solutions (Friedman, 1991; Sharda et al., 2008). MARS manner can be comprised of the complicated non-linear relationship among variables even if strong model assumptions (Lee \& Chen, 2005). The modeling process includes forward and backward steps. It can choose proper independent variables at forwarding steps to increase the model's performances and hamper over-fitting (Safari, 2019). This model comprises of basis functions that can be identified in a given interval and the last of points of the interval are called knots. At backward steps, too many knots are pruned to get a pure model (Friedman, 1991; Sharda et al., 2008). It is settled down on basis functions which project variable $\mathrm{X}$ to a new one called Y through using them:

$$
\begin{gathered}
Y=\max (0, X-c) \\
Y=\max (0, c-X)
\end{gathered}
$$

where $\mathrm{c}$ is a threshold value. It can be chosen the desired number of basis functions at the first step and it can eliminate redundant knots at backward steps (Safari, 2019).

Support Vector Machine (SVM) is a machine learning method that is enhanced by Vapnik for the solution of problems and patterns of recognition. By using this method identifies a hyperplane that separates two classes' optimal levels. This method is based on statistical learning theory and is used as the solution of classification and regression problems in high-dimensional data (Cortes \& Vapnik, 1995; Vapnik, 2010).

SVM carries out structural risk minimization principles instead of empirical risk minimization principles (Lin et al., 2006) so it aims to 
choose model complexity for limited observations (Stoean \& Stoean, 2014). Support Vector Machine is divided into Linear SVM and NonLinear SVM.

SVM seeks to find a function by minimizing the regression error. The minimization problem can be described as following (Law \& Shawe-Taylor, 2017):

$$
\begin{aligned}
\text { objective: } \min _{w, b} \frac{1}{2}\|w\|^{2}+C \sum_{i=1}^{n}\left(\xi_{i}^{+}+\xi_{i}^{-}\right) \\
\text {subject: } \begin{aligned}
& y_{i}-w \cdot x_{i}-b \leq \varepsilon+\xi_{i}^{+} \\
& w \cdot x_{i}+b-y_{i} \leq \varepsilon+\xi_{i}^{-} \\
& \xi_{i}^{+}, \xi_{i}^{-} \geq 0 \quad \forall i
\end{aligned}
\end{aligned}
$$

where $\mathrm{y}, \mathrm{x}$, and $\mathrm{b}$ are the dependent variable, independent variables, and error term, respectively. $\mathrm{w}$ represents the weight parameter of the model. To prevent overfitting, the regularization constraint can be used as the first term of the objective function. In the second term, $\varepsilon^{-}$ insensitive loss function is given. $\xi_{i}^{+}$and $\xi_{i}^{-}$are the slack variables in the optimization problem (Depren et al., 2021).

\section{Results}

Before running machine learning algorithms, descriptive statistics and the distributions of variables are calculated, which is shown in Figure 2.

The average score of CPI is 45 and the standard deviation (SD) is 18.6. The variation of Monetary Freedom, Tax Burden, and Trade Freedom is are relatively lower than others while the variation of Fiscal Health, Government Integrity, and Judicial Effectiveness are relatively higher than others. Once the average scores of dimensions of EFW are examined, it is seen that Tax Burden has the highest average score as 77.1 and Government Integrity has the lowest average score as 43.5. Also, Government Integrity, Tax Burden, Business Freedom, Labor Freedom, and Monetary Freedom have some outliers. 
After splitting data into two (train and test), two different machine learning algorithm with 10-fold and 5-repeat cross-validation approach is performed in the training dataset. After the model creation, these algorithms are tested in the testing dataset. The results of model performance for both datasets are given in Table 2 .

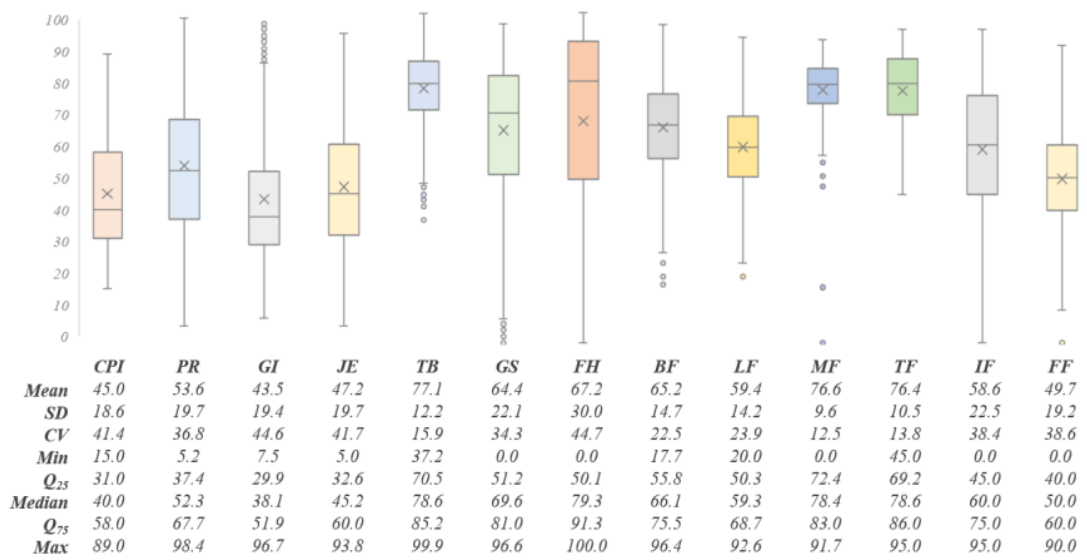

Figure 2. The Box-Whisker Plot and Descriptive Statistics of Variables

Table 2.

Model Performance Metrics

\begin{tabular}{lllll}
\hline Dataset & Algorithm & $\mathbf{R}^{\mathbf{2}}$ & RMSE & MAE \\
\hline \multirow{2}{*}{ Training Dataset } & MARS & $91.7 \%$ & 5.2929 & 3.8882 \\
& SVM & $89.8 \%$ & 5.8838 & 4.1523 \\
\multirow{2}{*}{ Test Dataset } & MARS & $92.5 \%$ & 5.2710 & 4.0953 \\
& SVM & $92.7 \%$ & 5.1871 & 3.6634 \\
\hline
\end{tabular}

According to Table 2, it is seen that the performance of the MARS and the SVM algorithms is high enough to interpret the model. Since the MARS algorithm can produce the mathematical formulation of the model, it is easy to interpret the model. Thus, MARS algorithm results are interpreted in this study. In this way, the result of the SVM can be 
used to validate the results of the MARS algorithm. The model output of the MARS algorithm is given in Table 3.

Table 3.

MARS Model Results

\begin{tabular}{llc}
\hline $\begin{array}{l}\text { Variable } \\
\text { Code }\end{array}$ & Basis Functions & Coefficients \\
\hline Intercept & Intercept & 60.885 \\
BF1 & $\max (88.3-\mathrm{PR} ; 0)$ & -0.152 \\
BF2 & $\max (50.9-\mathrm{GI} ; 0)$ & -0.647 \\
BF3 & $\max (\mathrm{GI}-50.9 ; 0)$ & 0.591 \\
BF4 & $\max (\mathrm{TB}-83.3 ; 0)$ & -1.612 \\
BF5 & $\max (\mathrm{GS}-40.6 ; 0)$ & -0.165 \\
BF6 & $\max (88.3-\mathrm{PR} ; 0) * \max (\mathrm{GI}-36.8 ; 0)$ & 0.009 \\
BF7 & $\max (88.3-\mathrm{PR} ; 0) * \max (\mathrm{TF}-62.3 ; 0)$ & -0.003 \\
BF8 & $\max (88.3-\mathrm{PR} ; 0) * \max (62.3-\mathrm{TF} ; 0)$ & -0.009 \\
BF9 & $\max (39.9-\mathrm{GI} ; 0) * \max (\mathrm{TB}-83.3 ; 0)$ & 0.055 \\
BF10 & $\max (\mathrm{GI}-39.9 ; 0) * \max (\mathrm{TB}-83.3 ; 0)$ & -0.021 \\
BF11 & $\max (\mathrm{JE}-47.1 ; 0) * \max (\mathrm{TB}-83.3 ; 0)$ & 0.051 \\
BF12 & $\max (\mathrm{TB}-83.3 ; 0) * \max (\mathrm{TF}-70.8 ; 0)$ & 0.097 \\
BF13 & $\max (\mathrm{TB}-83.3 ; 0) * \max (70.8-\mathrm{TF} ; 0)$ & -0.095 \\
BF14 & $\max (\mathrm{GS}-40.6 ; 0) * \max (\mathrm{IF}-75.0 ; 0)$ & 0.015 \\
BF15 & $\max (\mathrm{TB}-83.3 ; 0) * \max (70.8-\mathrm{TF} ; 0) * \mathrm{BF}$ & 0.004 \\
BF16 & $\max (\mathrm{TB}-83.3 ; 0) * \max (\mathrm{BF}-59.0 ; 0) * \max (\mathrm{TF}-$ & -0.003 \\
\hline & $70.8 ; 0)$ & \\
\hline & & \\
\hline
\end{tabular}

As a result of the model, there are 16 basis functions in the model. Based on Table III, Tax Burden has the highest impact on CPI while Property Rights has the lowest impact on CPI. When the basis functions are examined, it is revealed that PR should be higher than 88.3 to prevent the negative impact of it on CPI. Similar to Property Rights, 
Government Integrity should be higher than 50.9 to improve CPI. The Tax Burden should be lower than 83.3 to keep CPI at a lower level. Also, Government Spending hurts CPI if its value higher than 40.6.

Once the two-way and three-way interaction effects are examined, it is shown that two-way interaction effects among Property Rights, Government Integrity, and Tax Freedom are significantly important. Furthermore, two-way interaction effects among Tax Burden, Government Integrity, and Judicial Effectiveness, the interaction effect between Tax Burden and Tax Freedom, and three-way interaction effect among Tax Burden, Business Freedom, and Tax Freedom have a significant impact on CPI. As a result of these interaction effects, it is seen that if the Property Rights is lower than 88.3, Government Integrity should be higher than 36.8 , or Tax Freedom should be higher than 62.3 to improve CPI. Moreover, if the Tax Burden is higher than 83.3, Judicial Effectiveness should be higher than 47.1, or Tax Freedom should be higher than 70.8 to improve CPI. When the three-way interaction effect is examined, it is seen that if the Tax Burden is higher than 83.3 and Tax Freedom is higher than 70.8 then Business Freedom should be higher than 59.0 to reduce the negative effect of the two-way interaction of Tax Burden and Tax Freedom.

According to the coefficients of independent variables, the most important factors affecting CPI is the Tax Burden. The Government Integrity, Government Spending, and Property Rights are the second, third, and fourth important variables affecting CPI, respectively.

Train - MARS

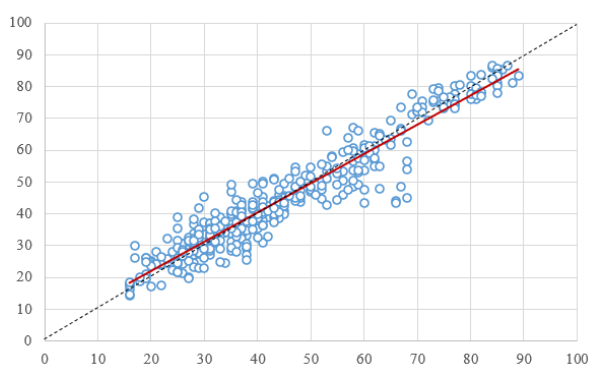

Test - MARS

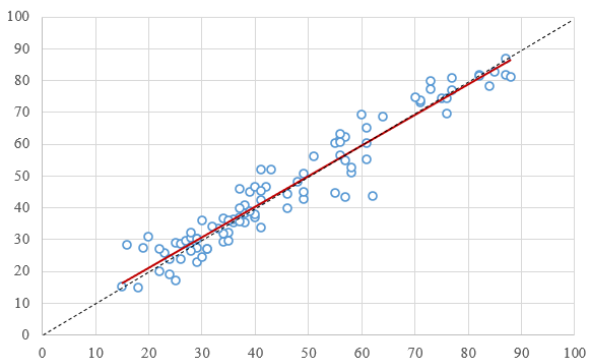

Figure 3. Actual and Predicted Values Obtained from Mars Algorithm in Both Train and Test Datasets. 
After the MARS algorithm interpretation, actual and predicted values of CPI are compared with plotting actual values placed on a horizontal line by predicted values placed on a vertical line. All data points are expected to be close to a 45-degree line in the Plot for a good model.

Based on Figure 3, actual and predicted values on the Q-Q Plot are very close to the 45-degree line, which means that model results can be interpreted.

\section{Discussion}

The dataset, which is obtained from the Economic Freedom Index Study of Heritage Foundation and the CPI of Transparency International, of this research consists of 486 observations within 162 countries in the years between 2017 and 2019. In this research, it is analyzed which dimensions of economic freedom have a significant impact on the corruption perception using the MARS algorithm.

As a result of the analysis, it is revealed that Tax Burden is the most influencing factor that should be focused on to improve the corruption perception followed by Government Integrity and Government Spending. Furthermore, Property Rights, Trade Freedom, and Investment Freedom are the factors that have a significant impact on corruption perception. Similar to the studies in the literature, it is shown that the nexus between marginal tax rate (or total tax burden as a percentage of GDP), which is the major metrics of the Tax Burden dimension, and the corruption perception is highly correlated (Damayanti et al., 2020; Myles \& Yousefi, 2020; Le et al., 2020). The relationship between Tax Burden and Corruption is described as it appears that there is less corruption when there is a low tax burden, thus taxpayers are intrinsically motivated to act more honestly and provide accurate information in these studies. This means that there is a positive correlation between tax burden and corruption perception, which is provided in this study as well.

Irregular payments and bribes and transparency of government policymaking are the major factors that compose the Government Integrity dimension of Economic Freedom. The correlation between 
transparency perception and corruption is explained as when the higher levels of transparency cause a lower level of corruption (Augustine \& Enyi, 2020; Kohler \& Dimancesco, 2020; Bauhr et al., 2019; Chen \& Neshkova, 2019; Peisakhin, 2012). Similar to the studies in the literature, it is shown that the high level of Government Integrity improves the corruption perception in this study.

Government Spending, which covers all the expenditures done by the government, is the third important factor affecting the corruption perception. Based on the extant literature, the impact of corruption on government spending (or vice versa) is examined by different researchers (Dzhumashev, 2013; Delavallade, 2006; Mauro, 1998). In these studies, it is explained the relationship between government spending and corruption is described as the increases in government spending causes a larger social loss induced by a rise in corruption. Similar to the studies in the literature, the same correlation is shown in this study.

In the studies of Lima and Delen (2020), Hallward-Driemeier (2013), and Dong and Torgler (2011), it was revealed that factors related to property rights are highly correlated to the corruption perception (Lima \& Delen, 2020; Hallward-Driemeier, 2013; Dong \& Torgler, 2011). Similar to the aforementioned studies, the Property Rights score should be high to reduce corruption. Thus, especially, physical property rights, intellectual property rights, the strength of investor protection, the risk of expropriation, and the quality of land administration should be improved to decline the corruption.

Finally, it is revealed that tariff rate and non-tariff barriers, which are dimensions of Trade Freedom, and restrictions on investments, payments, transfers, and capital transactions, which are dimensions of Investment Freedom, have a significant impact on the corruption in this study. The significant impact of Trade Freedom and Investment Freedom on Corruption is frequently emphasized in the literature (Shirazi, 2020; Cooray et al., 2020; Smidova, 2020; Qureshi et al., 2020; Zheng \& Xiao, 2020). Similar to the studies in the literature, a positive correlation between Trade Freedom, Investment Freedom, and Corruption is revealed in this study. Thus, tariff rates, non-tariff 
barriers, restrictions on investments, payments, transfers, and capital transactions should be improved to decline corruption.

\section{Conclusions and Recommendations}

Corruption perception is one of the key metrics to be measured, monitored, and improved for a country since it is affected by micro and macro determinants of different sectors. Thus, determining the main factors influencing the corruption perception would be crucial for policymakers to create action plans to improve the perception of corruption. In light of the mentioned importance, the nexus between the dimensions of Economic Freedom and the corruption perception is analyzed with two different algorithms in this study. As a result of the analysis, since the MARS algorithm is outperformed SVM, the output of the MARS algorithm is interpreted in detail.

Similar to the studies in the literature, it is revealed that Tax Burden, Government Integrity, and Government Spending are the most crucial factors that have a significant impact on corruption perception in this study. Thus, policymakers need to create action plans to improve corruption perception such as investor protection regulations, transparency of transactions of government, irregular payments, tax and tariff rates, and internal/external trade barriers. Firstly, actions that can prevent the tax burden problem are to create a development plan on how to improve income per capita, foreign trading volume, and the capacity of employment, which are highly correlated with tax burden (Çelikay, 2020; Adam et al., 2015). Since increasing foreign demand can provide a great employment capacity, the government should encourage firms to reveal key investments of the country, which can help to increase economic growth (Mondal, 2021). Secondly, the government should make a plan on providing a comprehensive government integrity agenda that has a 4-step action plan: (i) to re-create the audit system that based on investigation and law-enforcement, (ii) to provide a transparent electoral system, (iii) to disseminate information about the actions of the government in a transparent way, and (iv) to prevent the offering of bribes by encouraging the following of compliance programs (CAF, 2019). Thirdly, the increasing government spending 
on reducing corruption causes to reduce expenditures on general public services such as education, health, culture, and religion. This inefficient government management on allocating expenditure among related sectors leads to higher corruption (Hashem, 2014; Jajkowicz \& Drobiszová, 2015). Fourthly, Governments should encourage residents and social-political organizations to campaign against corruption or participate in the ongoing process of anti-corruption campaigns (Thach and Ngoc, 2021). Lastly, the policy of trade and investment freedom should be rearranged with a transparency perspective and maximum local benefits. In this process especially tariff rates, non-tariff barriers, and restrictions on investments, payments, transfers, and capital transactions should be taken into consideration to reduce corruption perception.

Although this research should be a reference study for future research, the study has some limitations. Although the relationship between the economic freedom dimensions and the corruption perception is analyzed, micro and macro economical metrics can be added to the model, and some other machine learning or deep learning algorithms can be evaluated to model the corruption for future research.

\section{References}

Adam, A., Kammas, P., \& Lapatinas, A. (2015). Income inequality and the tax structure: evidence from developed and developing countries, Journal of Comparative Economics, 43(1), 138-154. https://doi.org/10.1016/j.jce.2014.05.006

Andvig, J., \& Fjeldstad, O.-H. (2001). Corruption: A review of contemporary research. CMI Report R 2001:7. Chr. Michelsen Institute.

Astafurova. O. A., Borisova. A. S., Golomanchuk. E. V., \& Yagotinsteva. T. Y. (2020). Use of Modern Information Technologies for Countering Corruption in the Executive Authorities. International Journal of Information and Education Technology, 10(3), 209-214. https://doi.org/10.18178/ijiet.2020.10.3.1365 Augustine, A.A., \& Enyi, E. (2020). Control of Corruption, Trust in Government, and Voluntary Tax Compliance in South-West, Nigeria. 
58 Yangin \& Kllıç Depren - The Role of Economic Freedom

Management Studies, 8(1), 84-97. https://doi.org/10.17265/23282185/2020.01.011

Bauhr, M., Czibik, A., Licht, J. F., \& Fazekas, M. (2019). Lights on the shadows of public procurement: Transparency as an antidote to corruption, Governance, 33(3), 495-523.

https://doi.org/10.1111/gove.12432

Billger. S. M., \& Goel. R. K. (2009). Do Existing Corruption Levels Matter in Controlling Corruption?: Cross-country Quantile Regression Estimates, Journal of Development Economics, 90(2), 299-305. https://doi.org/10.1016/j.jdeveco.2008.07.006

Budsaratragoon, P., \& Jitmaneeroj, B. (2020). A critique on the Corruption Perceptions Index: An interdisciplinary approach, Socio-Economic Planning Sciences, 70, 100768.

https://doi.org/10.1016/j.seps.2019.100768

Carden. A., \& Verdon. L. (2010). When is corruption a substitute for economic freedom? Law and Development Review, 3, 40-63. https://papers.ssrn.com/sol3/papers.cfm?abstract_id=1132751

CAF (2019). RED 2019. Integridad en las políticas públicas: claves para prevenir la corrupción.

http://scioteca.caf.com/handle/123456789/1503

Chen, C., \& Neshkova, M.I. (2019). The effect of fiscal transparency on corruption: A panel cross-country analysis. Public Administration, 98(1), 226-243. https://doi.org/10.1111/padm.12620

Chowdhury. S. (2004). The effect of democracy and press freedom on corruption: An empirical test. Economics Letters, 85, 93-101. https://doi.org/10.1016/j.econlet.2004.03.024

Christos, P., Eleni, K., Dimitrios, K., Zacharias, D., Athanasios, A., \& Panagiotis, L. (2018). Corruption Perception Index (CPI), as an Index of Economic Growth for European Countries. Theoretical Economics Letters, 8(3), 82541. https://doi.org/10.4236/tel.2018.83037

Cooray, A., Jha, C.K., \& Panda, B. (2020). Corruption and assortative matching of partners in international trade, WIDER Working Paper Series wp-2020-114, World Institute for Development Economic Research (UNU-WIDER).

Cortes. C., \& Vapnik. V. (1995). Support-Vector Networks. Machine Learning, 20, 273-297. 
Cuadrado-Ballesteros. B., \& Pena-Miguel. N. (2020). Corruption Perception Following Privatization Reforms: The Moderating Role of the Quality of Governance. Revista De Contabilidad. 23(1), 127-137.

https://doi.org/10.6018/rcsar.361041

Çelikay, F. (2020). Dimensions of tax burden: a review on OECD countries.

Journal of Economics, Finance and Administrative Science, 25(49), 27-43.

Damayanti, T.W., Prabowo, R., Sucahyo, U.S., \& Supramano, S. (2020).

The Relationship between Gender, Tax Burdens, Corruption Practices, and Tax Compliance. Journal of Southwest Jiaotong University, 55(3), 1-12. https://doi.org/10.35741/issn.0258-2724.55.3.54

de Jong. E., \& Bogmans. C. (2011). Does corruption discourage international trade? European Journal of Political Economy, 27, 385398. https://doi.org/10.1016/j.ejpoleco.2010.11.005

Debski, J., Jetter, M., Mösle, S., \& Stadelmann, D. (2018). Gender and corruption: the neglected role of culture. European Journal of Political Economy, 55(December), 526-537.

Delavallade, C. (2006). Corruption and distribution of public spending in developing countries. Journal of Economics and Finance, 30, 222239. https://link.springer.com/article/10.1007/BF02761488

Depren, Ö., Kartal, M.T., \& Kılıç Depren, S. (2021). Recent Innovation in Benchmark Rates (BMR): Evidence from Influential Factors on Turkish Lira Overnight Reference Interest Rate with Machine Learning Algorithms. Financial Innovation, 7(44), 1-20. https://doi.org/10.1186/s40854-021-00245-1

Dong, B., \& Torgler, B. (2011). Corruption and Social Interaction: Evidence from China. Dong, Bin and Torgler, Benno, Corruption and Social Interaction: Evidence from China (February 7, 2011). FEEM Working Paper No. 9.2011. https://ssrn.com/abstract=1756843

Dzhumashev, R. (2013). The two-way relationship between government spending and corruption and its effects on economic growth.

Contemporary Economic Policy, 32(2), 403-419.

https://doi.org/10.1111/coep.12025

Fazira, D.R., \& Cahyadin, M. (2018). The Impact of Interest Rate, Corruption Perception Index, and Economic Growth on Foreign 
60 Yangın \& Kılıç Depren - The Role of Economic Freedom

Direct Investment in ASEAN-6. Jurnal Keuangan dan Perbankan, 22(4), 707-713.

Friedman. J. H. (1991). Multivariate Adaptive Regression Splines. The Annals of Statistics, 19(1), 1-67.

Goel. R., \& Nelson. M. (2007). Are corrupt acts contagious? Evidence from the United States. Journal of Policy Modeling, 29, 839-850.

https://doi.org/10.1016/j.jpolmod.2007.09.002

Groenendijk, N. (1997). A principal-agent model of corruption. Crime. Law and Social Change, 27(3-4), 207-229.

Gwartney. J., Lawson. R., Hall. J., Murphy. R., Bennett. D. L., Fike. R., \&

Nikolaev. B. (2019). Economic Freedom of the World: 2019 Annual

Report. Vancouver. Fraser Institute.

Hallward-Driemeier, M. (2013). Who Survives? The Impact of Corruption, Competition and Property Rights Across Firms. Policy Research Working Papers, World Bank. https://doi.org/10.1596/1813-94505084

Hashem, A.H. (2014). The Effects of Corruption on Government

Expenditures: Arab Countries Experience. Journal of Economics and Sustainable Development, 5(4), 120-130.

Huang, C-H. (2016). Is corruption bad for economic growth? Evidence from Asia-Pacific countries. The North American Journal of Economics and Finance, 35, 247-256. https://doi.org/10.1016/j.najef.2015.10.013 Jajkowicz, O., \& Drobiszová, A. (2015). The Effect of Corruption on Government Expenditure Allocation in OECD Countries. ACTA Universitatis Agriculturae et Silviculturae Mendelianae Brunensis, 63(138), 1251-1259.

Keyifli. N. (2019). E-government and corruption: an empiric analysis. Global Journal of Economics and Business Studies, 8(16), 196-206. https://doi.org/10.1080/01900690701590553

Kohler, J.C., \& Dimancesco, D. (2020). The risk of corruption in public pharmaceutical procurement: How anti-corruption, transparency and accountability measures may reduce this risk. Global Health Action, 13(1), 1-10. https://doi.org/10.1080/16549716.2019.1694745

Konu. A., \& Ata. A. Y. (2016). Yolsuzluk ve Ekonomik Özgürlükler İlişkisi: AB Ülkeleri Üzerine Yatay Kesit Analizi. Niğde Üniversitesi İktisadi ve İdari Bilimler Fakültesi Dergisi, 9(1), 195-207. 
Law, T., \& Shawe-Taylor, J. (2017). Practical bayesian support vector regression for financial time series prediction and market condition change detection. Quantitative Finance, 17(9), 1403-1416.

Le, D.T., Malesky, E., \& Pham, A. (2020). The impact of local corruption on business tax registration and compliance: Evidence from Vietnam. Journal of Economic Behavior \& Organization, 177, 762-786. https://doi.org/10.1016/j.jebo.2020.07.002

Lee. T.-S., \& Chen. I.-F. (2005). A two-stage hybrid credit scoring model using artificial neural networks and multivariate adaptive regression splines. Expert Systems with Applications, 28(4), 743-752. https://doi.org/10.1016/j.eswa.2004.12.031

Lima. M.S.M., \& Delen. D. (2020). Predicting and Explaining Corruption Across Countries: A Machine Learning Approach. Government Information Quarterly, 37(1), 1-15. https://doi.org/10.1016/j.giq.2019.101407

Lin, J., Cheng, C-T., \& Chau, K-W. (2006). Using Support Vector Machines for Long-Term Discharge Prediction. Hydrological Sciences Journal, 51 (4), 599-612. https://doi.org/10.1623/hysj.51.4.599

Marquette, H., \& Peiffer, C. (2015). Corruption and Collective Actions. U4 Anti-Corruption Resource Centre, Chr. Michelsen Institute. Mauro, P. (1998). Corruption and the composition of government expenditure. Journal of Public Economics, 69, 263-279. https://ideas.repec.org/a/eee/pubeco/v69y1998i2p263-279.html

Mondal, P. (2021). Contribution of Foreign Trade to Economic Growth.

Your Article library. https://www.yourarticlelibrary.com/foreigntrade/contribution-of-foreign-trade-to-economic-growth/40276

Myles, G.D., \& Yousefi, H. (2020). Corruption as an Occupational Choice: Endogenous Corruption and Tax Policy. Southern Economic Journal, 86, 1446-1474. https://doi.org/10.1002/soej.12421

Peisakhin, L.V. (2012). Transparency and Corruption: Evidence from India.

The Journal of Law and Economics, 55(1), 129-149.

https://doi.org/10.1086/663727

Persson, A., Rothstein, B., \& Teorell, J. (2013). Why Anticorruption Reforms fail: Systemic corruption as a collective action problem. Governance, 26(3), 449-471. 
Pieroni. L., \& d'Agostino. G. (2013). Corruption and The Effects of Economic Freedom. European Journal of Political Economy, 29, 5472. https://doi.org/10.1016/j.ejpoleco.2012.08.002

Qaiser, B., Nadeem, S., Siddiqi, M.U., \& Siddiqui, A.F. (2017). Relationship of Social Progress Index (SPI) with Gross Domestic Product (GDP PPP per capita): The Moderating Role of Corruption Perception Index (CPI). Pakistan Journal of Engineering, Technology \& Science, 7(1), 61-76. http://dx.doi.org/10.22555/pjets.v7i1.2083

Qureshi, F., Qureshi, S., Vo, X.V., \& Junejo, I. (2020). Revisiting the nexus among foreign direct investment, corruption and growth in developing and developed markets. Borsa Istanbul Review. https://doi.org/10.1016/j.bir.2020.08.001

Safari. M. J. (2019). Decision tree (DT), generalized regression neural network (GR) and multivariate adaptive regression splines (MARS) models for sediment transport in sewer pipes. Water Science \& Technology, 79(6), 1113-1122. https://doi.org/10.2166/wst.2019.106

Saha. S., Gounder. R., \& Su. J. (2009). The interaction effect of economic freedom and democracy on corruption: A panel cross-country analysis. Economics Letters, 105, 173-176. https://doi.org/10.1016/j.econlet.2009.07.010

Sharda. V. N., Prasher. S. O., Patel. R. M., Ojasvi. P. R., \& Prakash. C. (2008). Performance of Multivariate Adaptive Regression Splines (MARS) in predicting runoff in mid-Himalayan micro-watersheds with limited data. Hydrological Sciences Journal, 53(6), 1165-1175. https://doi.org/10.1623/hysj.53.6.1165

Shirazi, M.A. (2020). The Impact of Corruption on International Trade. Denver Journal of International Law \& Policy, 40(1), 435-446. https://doi.org/10.1111/j.1467-9701.2012.01436.x

Smidova, Z. (2020). Building the evidence for OECD integrity and anticorruption agenda: The current situation and avenues for future analysis. OECD Economics Department Working Papers, No: 1614. https://doi.org/10.1787/80ebe6e6-en

Stensöta, H., Svensson, R., \& Wängnerud, L. (2015). Gender and Corruption: the mediating power of institutional logics. Governance: An international Journal of Policy, Administration, and Institutions, 28(4), 475-496. 
International and Multidisciplinary Journal of Social Sciences, 10(3) 63

Stephen, J. (2018). Corruption is costing the global economy \$3.6 trillion dollars every year. The World Economic Forum.

https://www.weforum.org/agenda/2018/12/the-global-economy-loses3-6-trillion-to-corruption-each-year-says-u-n

Stoean. C., \& Stoean. R. (2014). Support vector machines and evalutionary algorithms for classification. Springer-Verlag.

Thach, N. N., \& Ngoc, B.H. (2021). Impact of Economic Freedom on Corruption Revisited in ASEAN Countries: A Bayesian Hierarchical Mixed-Effects Analysis. Economies, 9(3), 1-16.

Transparency International (2020, June 04). What-is-corruption.

Transparency International Website.

https://www.transparency.org/en/what-is-corruption

Treisman. D. (2007). What have we learned about the causes of corruption from ten years of cross-national empirical research? Annual Reviews Political Science, 10, 211-244.

https://www.annualreviews.org/doi/abs/10.1146/annurev.polisci.10.08 1205.095418

Vapnik, V. (2010). The Nature of Statistical Learning Theory. SpringerVerlag.

Vendrell-Herrero, F., Darko, C., \& Vaillant, Y. (2020). Firm productivity and government contracts: The moderating role of corruption. SocioEconomic Planning Sciences.

https://doi.org/10.1016/j.seps.2020.100899

Zheng, B., \& Xiao, J. (2020). Corruption and Investment: Theory and

Evidence from China. Journal of Economic Behavior \& Organization, 175, 40-54. https://doi.org/10.1016/j.jebo.2020.03.018

Serpil Kılıç Depren is an Assoc. Prof. Dr. of Statistics at Yildiz Technical University, Turkey

Gülçin Yangın is a PhD student of Statistics at Yildiz Technical University, Turkey

Email: serkilic@yildiz.edu.tr 